\title{
Current Nutritional Factors Affecting Fertility and Infertility
}

\author{
Hande Çekici*
}

Department of Nutrition and Dietetics, College of Health, Recep Tayyip Erdoğan University, Rize, Turkey

${ }^{*}$ Corresponding author: Dr. Hande Çekici, Department of Nutrition and Dietetics, College of Health, Recep Tayyip Erdoğan University, Rize, Turkey, Tel: +90 46422361 26; E-mail: handecekici@hotmail.com

Received: February 28, 2018; Accepted: March 20, 2018; Published: March 25, 2018

Citation: Çekici H (2018) Current Nutritional Factors Affecting Fertility and Infertility. Ann Clin Lab Res Vol.6: No.1: 225.

\section{Commentary}

Ovulatory fertility is defined as the release of an egg from the ovary, must happen in order to achieve pregnancy. In case of a defect in the ovulation process, the final result of anovulation may be encountered. Anovulation is an important gynecological problem that women have adequate estrogens but no ovulation and it commonly presents with irregular menstruation oramenorrhea [1]. Chronic anovulation is a condition as long intervals between menstrual cycles for more than 35 days, or amenorrhea for at least 6 months [1]. Infertility is a widespread disorder which is defined as the inability to achieve conceive after a period of 12 months of unprotected intercourse $[2,3]$.

There are many factors that affect fecundability and infertility. Some of these factors, such as age and genetic factors, cannot be changed unfortunately. However, there is definite evidence that replaceable factors, like unhealthy diet, excessive alcohol, smoking and gaining weight, negatively affect reproductive health [4]. The fact that certain dietary ingredients are deemed responsible for male and female infertility makes it crucial to study the effects of nutrition on infertility and reproductive health. Especially trans fatty acids have adverse effects on male and female reproductive health, cause abnormalities in certain metabolic pathways and damage the metabolism of essential components of the reproductive system $[5,6]$. When other nutritional factors that may be responsible for infertility are evaluated; saturated fat, red meat, processed meats, fatty dairy products, sugar and sweeteners, alcohol and caffeine come to the forefront. In addition, the high consumption of soy and soy products may increase the risk of infertility in male [7]. On the other hand, protective foods against infertility such as fish, poultry, fruits and vegetables and whole-grains reduce the risk of male and female infertility by various mechanisms of action [8]. While a high western style diet with high saturated fat, trans fat and sugar is associated with a high risk of infertility, whereas prudent diet that contains much more vegetables, fruits, grains and fish is associated with a low risk of infertility. The low-fat dairy products significantly enhance sperm concentration and progressive motility [9]. The hourglass in Figure 1 summarizes the factors that increase or decrease the risk of infertility in male and female [5].

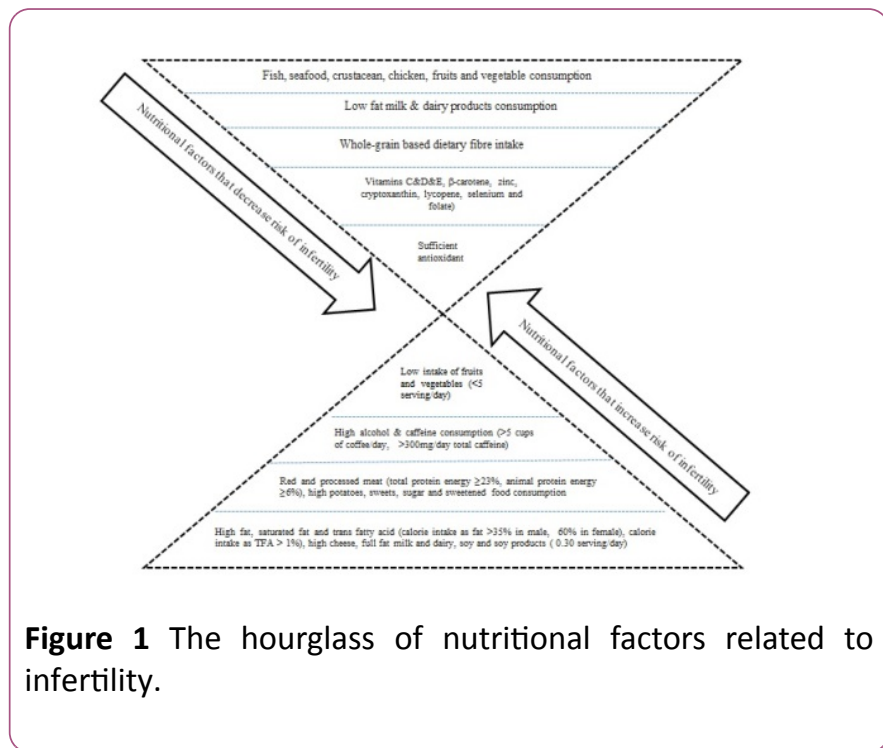

Various current studies have examined the relationship between nutrients and infertility; saturated fatty acids, monounsaturated fatty acids, energy derived from fat adversely affects semen quality, sperm concentration and sperm parameters [10], processed meat is associated with lower sperm count and lower progressive motile sperm and abnormal sperm morphology [11,12]. Besides, the other factor that decreases to sperm motility and negatively alters the sperm morphology is whole-fat dairy product [13]. Conversely, the higher concentrations of omega-3 improve semen parameters and sperm morphology and motility [14]. When the effects of foods on the female fertility are evaluated, citrus fruits decrease risk of endometriosis $[15,16]$, higher intake of whole grain is related to higher probability of live birth among women [17], poultry consumption is positively associated with fertilization rates and it supports fecundability [18]. Tables 1 and $\mathbf{2}$ summarize the studies related with various nutritional factors that affect negatively or positively to male/female fertility [19-49].

The articles considered in this commentary have indicated that dietary ingredients may be deemed responsible for male and female infertility and at the same time some nutrients may significantly decreases the risk of infertility and improve fecundability. As a result, vital regulations in the diet which is a modifiable factor in the risk of infertility, will lead to positive feedbacks on reproductive health. 
Table 1 The various nutritional factors that have negative effects on male/female fertility.

\begin{tabular}{|c|c|c|}
\hline Factors & Results & Studies (References) \\
\hline \multirow[t]{3}{*}{ Trans fatty acids } & $\begin{array}{l}\text { High intake of trans fatty acids cause significant decline in } \\
\text { sperm concentration and sperm count. }\end{array}$ & \multirow[t]{3}{*}{ [19-25] } \\
\hline & $\begin{array}{l}\text { Trans fatty acids play a negative role in reproduction by } \\
\text { increasing risk of ovulatory infertility in women with polycystic } \\
\text { ovary syndrome. }\end{array}$ & \\
\hline & $\begin{array}{l}\text { Trans fatty acids demonstrate positive correlation with } \\
\text { asthenospermia. }\end{array}$ & \\
\hline \multirow[t]{6}{*}{ Alcohol } & $\begin{array}{l}\text { Alcohol consumption reduces the fertilization rate and } \\
\text { negatively affects fecundability. }\end{array}$ & \multirow[t]{6}{*}{ [16], [26-31] } \\
\hline & $\begin{array}{l}\text { Moderate alcohol consumption positively affects levels of } \\
\text { serum testosterone and does not harm semen quality. }\end{array}$ & \\
\hline & $\begin{array}{l}\text { Alcohol consumption found to be related to low sperm volume } \\
\text { and high sperm DNA fragmentation. Infertile men who drink } \\
\text { alcoholic beverages } 2-3 \text { units per day have worse semen } \\
\text { quality compared with occasional drinkers ( }<3 \text { units per week). }\end{array}$ & \\
\hline & $\begin{array}{l}\text { Alcohol consumption is associatied with deterioration of most } \\
\text { semen properties. }\end{array}$ & \\
\hline & $\begin{array}{l}\text { The intake of the modest alcohol ( } 5 \text { units in a week) negatively } \\
\text { affect semen quality. }\end{array}$ & \\
\hline & $\begin{array}{l}\text { Alcohol consumption increases the numbers of morphologically } \\
\text { abnormal sperm. }\end{array}$ & \\
\hline \multirow[t]{5}{*}{ Red meat and processed meat } & Processed meat is the risk factor of asthenozoospermia. & \multirow[t]{5}{*}[11]{$,[12],[32-35]}$, \\
\hline & $\begin{array}{l}\text { Processed meat is associated with lower sperm count and } \\
\text { lower progressive motile sperm and abnormal sperm } \\
\text { morphology. }\end{array}$ & \\
\hline & $\begin{array}{l}\text { The consumption of red meat is associated with a greater rate } \\
\text { of ovulatory disorder infertility. Frequent intake of meat } \\
\text { products may adversely affect semen quality. }\end{array}$ & \\
\hline & $\begin{array}{l}\text { Semen parameters may be enhanced by diets which include } \\
\text { restricted processed meats and cheese. }\end{array}$ & \\
\hline & $\begin{array}{l}\text { Sausage and turkey ham intake may adversely affect assisted } \\
\text { reproductive parameters. }\end{array}$ & \\
\hline Sugars & Sugar decreases sperm motility. & [36] \\
\hline \multirow[t]{2}{*}{ Soy foods } & $\begin{array}{l}\text { A higher intake of soy foods may decrease sperm } \\
\text { concentration. }\end{array}$ & \multirow[t]{2}{*}{ [37] } \\
\hline & $\begin{array}{l}\text { The consumption of soy ( } 0.30 \text { serving/day) increases the risk of } \\
\text { infertility in males. }\end{array}$ & \\
\hline \multirow[t]{2}{*}{ Dairy products } & $\begin{array}{l}\text { The consumption of whole-fat dairy products decreases to } \\
\text { sperm motility and negatively alters the sperm morphology. }\end{array}$ & \multirow[t]{2}{*}{ [13], [38] } \\
\hline & $\begin{array}{l}\text { Higher dairy protein intake }(\geq 5.24 \% \text { of energy }) \text { of women } \\
\text { treated with infertility is associated with lower antral follicle } \\
\text { counts. }\end{array}$ & \\
\hline Caffeine & $\begin{array}{l}\text { The live birth rate of couples which male partner consume } \\
\text { caffeine } \geq 272 \mathrm{mg} / \text { day is approximately } 3 \text { times lower than } \\
\text { couples which male partner consume caffeine }<99 \text { mg/day. }\end{array}$ & [39] \\
\hline Coffee & $\begin{array}{l}\text { Pre-pregnancy coffee consumption ( } \geq 4 \text { servings/day) increases } \\
\text { risk of spontaneous abortion especially at weeks } 8-19 \text {. There } \\
\text { is no spontaneous abortion relation of caffeinated tea and } \\
\text { caffeinated soda. }\end{array}$ & [40] \\
\hline Weight gain & $\begin{array}{l}\text { During adulthood being overweight or being obesity or gaining } \\
\text { weight and being underweight at eighteen years old are } \\
\text { associated with a modest reduction in fecundity. }\end{array}$ & [41] \\
\hline
\end{tabular}




\begin{tabular}{|c|c|c|}
\hline \multirow[t]{3}{*}{ Lacto-ovo vegetarian diet and vegan diet } & Vegetables-based food intake decreases sperm quality. & \multirow[t]{3}{*}{ [42] } \\
\hline & $\begin{array}{l}\text { The sperm concentration of lacto-ovo vegetarians was found } \\
\text { significantly lower than non-vegetarians. }\end{array}$ & \\
\hline & $\begin{array}{l}\text { Total sperm motility was found lower in the lacto-ovo and vegan } \\
\text { groups than non-vegetarians. Vegans had lowest hyperactive } \\
\text { motility. }\end{array}$ & \\
\hline Genetically modified food/organism & $\begin{array}{l}\text { Genetically modified food/organism can be potential risk on } \\
\text { reproduction, through influencing the endocrine metabolism. }\end{array}$ & [43] \\
\hline \multirow[t]{4}{*}{$\begin{array}{l}\text { Fat and fatty acids and energy and } \\
\text { carbohydrates }\end{array}$} & $\begin{array}{l}\text { While saturated fatty acids, monounsaturated fatty acids, } \\
\text { energy derived from fat have statistically significant positive } \\
\text { correlation with immotiliy where as there is a statistically } \\
\text { negative correlation between the energy value of the diet and } \\
\text { sperm concentration. }\end{array}$ & \multirow[t]{4}{*}{ [10], [34], [44], } \\
\hline & $\begin{array}{l}\text { Energy derived from the carbohydrates is associated with lower } \\
\text { semen volume, consistency. }\end{array}$ & \\
\hline & $\begin{array}{l}\text { The energy derived from fat is associated with lower sperm } \\
\text { consistency and immotility. }\end{array}$ & \\
\hline & $\begin{array}{l}\text { Total fat intake increases testosterone concentrations in } \\
\text { healthy women in a very small way and it is inversely } \\
\text { associated with the high embryo quality rate. }\end{array}$ & \\
\hline
\end{tabular}

Table 2 The various nutritional factors that have positive effects on male/female fertility.

\begin{tabular}{|c|c|c|}
\hline Factors & Results & Studies \\
\hline Mediterranean diet & $\begin{array}{l}\text { Persistence of the Mediterranean diet (characterized by high intakes of } \\
\text { vegetables, fruits and seafood) support the higher sperm concentration and } \\
\text { total sperm count and sperm motility. }\end{array}$ & {$[45],[46]$} \\
\hline \multirow[t]{2}{*}{ Poultry } & $\begin{array}{l}\text { Inadequate intake of poultry was associated with a significantly higher risk } \\
\text { of asthenozoospermia. Therefore, intake of poultry decreases the risk of } \\
\text { asthenozoospermia. }\end{array}$ & \multirow[t]{2}{*}{ [12], [18] } \\
\hline & $\begin{array}{l}\text { Poultry intake was positively associated with fertilization rates and supports } \\
\text { fecundability. }\end{array}$ & \\
\hline \multirow[t]{2}{*}{ Fish } & Semen parameters may be enhanced by a rich diet from fish. & \multirow[t]{2}{*}{ [32] } \\
\hline & Fish intake positively affects total sperm count and sperm morphology. & \\
\hline \multirow[t]{5}{*}{ Fruits and vegetables } & $\begin{array}{l}\text { Daily intake of citrus fruits which are high in beta-cryptoxanthin }(\geq 1 \\
\text { servings) decreases risk of endometriosis (aproximately 22\%) compared to } \\
\text { consuming less than } 1 \text { per week. }\end{array}$ & \multirow[t]{5}{*}{ [15], [16], [35] } \\
\hline & $\begin{array}{l}\text { Daily intake of cruciferous vegetables ( } \geq 1 \text { servings) has a } 13 \% \text { higher risk } \\
\text { of endometriosis compared to those consuming less than } 1 \text { per week. }\end{array}$ & \\
\hline & The consumption of fruit is positively associated with sperm motility. & \\
\hline & Fruits or vegetables may maintain or improve semen quality. & \\
\hline & $\begin{array}{l}\text { Low intake of fruits and vegetables ( }<5 \text { serving/day) increases the risk of } \\
\text { infertility in males. }\end{array}$ & \\
\hline Lycopene & Lycopene positively affects sperm morphology & [47] \\
\hline \multirow[t]{2}{*}{ Low-fat dairy products } & It is associated with a higher sperm concentration and progressive motility. & \multirow[t]{2}{*}{ [9], [32] } \\
\hline & Semen parameters may be improved by consumption of low-fat dairy. & \\
\hline \multirow[t]{2}{*}{ Whole grain } & $\begin{array}{l}\text { Higher intake of whole grain includes specific nutrients such as phytic acid, } \\
\text { vitamin } E \text {, and selenium at pre-treatment period was related to higher } \\
\text { probability of live birth among women undergoing in vitro fertilization. }\end{array}$ & \multirow[t]{2}{*}[16]{,$[17]$} \\
\hline & The consumption of cereals is positively associated with sperm motility. & \\
\hline Omega-3 & $\begin{array}{l}\text { Proven fertile men have higher concentrations of omega- } 3 \text { fatty acids in } \\
\text { blood and spermatozoa than infertile men. }\end{array}$ & [14], [48] \\
\hline
\end{tabular}


Prudent diet (contains high consumption of fish, poultry, fruit, vegetables, legumes and whole grains)

There is a strong reverse correlation between the arachidonic
acid:docosahexaenoic acid and arachidonic acid:eicosapentaenoic acid
ratios and total sperm count, sperm motility and sperm morphology.
The omega- 3 increases antioxidant activity in human seminal fluid and
improves sperm count, motility, and morphology.
Intake of increased docosapentaenoic acid decreases the risk of
anovulation.
There is a positive correlation between prudent pattern and the percentage
of progressively motile sperm but no strong correlation between prudent
pattern and sperm concentration and morphology.

\section{References}

1. Chandeying P, Pantasri T (2015) Prevalence of conditions causing chronic anovulation and the proposed algorithm for anovulation evaluation. J Obstet Gynaecol Res 41: 74-1079.

2. Mollaahmadi F, Moini A, Salman Yazdi R, Behmanesh M (2018) The rs1127354 polymorphism in ITPA is associated with susceptibility to infertility. Cell J 20: 73-77.

3. Zhou Z, Zheng D, Wu H, Li R, Xu S, et al. (2018) Epidemiology of infertility in China: a population-based study. BJOG 125: 432441.

4. Rossi BV, Abusief M, Missmer SA (2014) Modifiable risk factors and Infertility: what are the connections? Am J Lifestyle Med 10: 220-231.

5. Çekici $H$, Akdevelioglu $Y$ (2018) The association between trans fatty acids, infertility and fetal life: A review. Hum Fertil (Camb) 31: 1-10.

6. Iqbal MP (2014) Trans fatty acids- a risk factor for cardiovascular disease. Pak J Med Sci 30: 194-197.

7. Giahi L, Mohammadmoradi S, Javidan A, Sadeghi MR (2016) Nutritional modifications in male infertility: a systematic review covering 2 decades. Nutr Rev 74: 118-130.

8. Salas-Huetos A, Bulló M, Salas-Salvadó J (2017) Dietary patterns, foods and nutrients in male fertility parameters and fecundability: a systematic review of observational studies. Hum Reprod Update 23: 371-389.

9. Afeiche M, Bridges N, Williams P, Gaskins A (2014) Dairy intake and semen quality among men attending a fertility clinic. Fertil Steril 101: 1280-1287.

10. Książek $A$, Zagrodna $A$, Słowińska-Lisowska $M$, Jóźków $P$, Lwow $F$, et al. (2018) Diet and semen quality in healty males from the population of the Lower Silesia Region in Poland. J Mens Health 14: 24-31.

11. Afeiche MC, Williams PL, Gaskins AJ, Mendiola J, Jørgensen N, et al. (2014) Meat intake and reproductive parameters among young men. Epidemiology 25: 323-330.

12. Eslamian G, Amirjannati N, Rashidkhani B, Sadeghi MR, Hekmatdoost A (2012) Intake of food groups and idiopathic asthenozoospermia: A case-control study. Hum Reprod 27: 3328-3336.

13. Afeiche M, Williams PL, Mendiola J, Gaskins A, Jørgensen N, et al. (2013) Dairy food intake in relation to semen quality and reproductive hormone levels among physically active young men. Hum Reprod 28: 2265-2275.
14. Safarinejad MR, Safarinejad S (2012) The roles of omega-3 and omega- 6 fatty acids in idiopathic male infertility. Asian J Androl 14: 514-515.

15. Harris HR, Eke AC, Chavarro JE, Missmer SA (2018) Fruit and vegetable consumption and risk of endometriosis. Hum Reprod 1-13.

16. Braga DP, Halpern G, Figueira Rde C, Setti AS, laconelli A, et al. (2012) Food intake and social habits in male patients and its relationship to intracytoplasmic sperm injection outcomes. Fertil Steril 97: 53-59.

17. Gaskins AH, Chiu YH, Williams PL, Keller MG, Toth $T L$, et al. (2016) Maternal whole grain intake and outcomes of in vitro fertilization. Fertil Steril 105: 1503-1510.

18. Xia W, Chiu Y, Williams P, Gaskins A, Toth T, et al. (2015) Men's meat intake and treatment outcomes among couples undergoing assisted reproduction. Fertil Steril 104: 972-979.

19. Chavarro JE, Minguez-Alarcon L, Mendiola J, Cutillas-Tolın A, Lopez-Espın JJ, et al. (2014) Trans fatty acid intake is inversely related to total sperm count in young healthy men. Hum Reprod 29: 429-440.

20. Attaman JA, Toth TL, Furtado J, Campos H, Hauser R, et al. (2012) Dietary fat and semen quality among men attending a fertility clinic. Hum Reprod 27: 1466-1474.

21. Jensen TK, Heitmann BL, Jensen MB, Halldorsson TI (2013) High dietary intake of saturated fat is associated with reduced semen quality among 701 young Danish men from the general population. Am J Clin Nutr 97: 411-418.

22. Chavarro JE, Attaman JA, Toth TL, Ford JB, Keller M, et al. (2011) Intake of trans fatty acids and semen quality among men attending a fertility clinic. Fertil Steril 96: 14-15.

23. Chavarro JE, Furtado J, Toth TL, Ford J, Keller M, et al. (2011) Trans-fatty acid levels in sperm are associated with sperm concentration among men from an infertility clinic. Fertil Steril 95: 1794-1797.

24. Ghaffarzad A, Amani R, Darabi M, Ghaffarzad A, Sadaghiani MM, et al. (2014) Correlation of erythrocyte trans fatty acids with ovulatory disorder infertility in polycystic ovarian syndrome. ABCMED 2: 8-18.

25. Eslamian G, Amirjannati N, Rashidkhani B, Sadeghi MR, Baghestani AR, et al. (2015) Dietary fatty acid intakes and asthenozoospermia: A case-control study. Fertil Steril 103: 190-198.

26. Jensen TK, Gottschau M, Madsen JO, Andersson AM, Lassen TH, et al. (2014) Habitual alcohol consumption associated with reduced semen quality and changes in reproductive hormones; a cross sectional study among 1221 young Danish men. BMJ Open 4: e005462. 
27. Jensen TK, Swan S, Jorgensen N, Toppari J, Redmon B, et al. (2014) Alcohol and male reproductive health: a cross-sectional study of 8344 healthy men from Europe and the USA. Hum Reprod 29: 1801-1809.

28. Anifandis G, Bounartzi T, Messini Cl, Dafopoulos K, Sotiriou S, et al. (2014) The impact of cigarette smoking and alcohol consumption on sperm parameters and sperm DNA fragmentation (SDF) measured by Halosperm. Arch Gynecol Obstet 290: 777-782.

29. Condorelli RA, Calogero AE, Vicari E, La Vignera S (2015) Chronic consumption of alcohol and sperm parameters: our experience and the main evidences. Andrologia 47: 368-379.

30. Hansen ML, Thulstrup AM, Bonde JP, Olsen J, Håkonsen, LB, et al. (2012) Does last week's alcohol intake affect semen quality or reproductive hormones? A cross-sectional study among healthy young Danish men. Reprod Toxicol 34: 457-462.

31. Joo KJ, Kwon YW, Myung SC, Kim TH (2012) The effects of smoking and alcohol intake on sperm quality: light and transmission electron microscopy findings. J Int Med Res 40: 23272-23335.

32. Afeiche $M$, Gaskins A, Williams P, Toth T, Wright D, et al. (2014) Processed meat intake is unfavorably and fish intake favorably associated with semen quality indicators among men attending a fertility clinic. J Nutr 144: 1091-1098.

33. Chavarro JE, Rich-Edwards JW, Rosner BA, Willett WC (2008) Protein intake and ovulatory infertility. Am J Obstet Gynecol 198: e1-7.

34. Kazemi A, Ramezanzadeh F, Nasr-Esfahani MH (2014) Relationship between dietary fat intake, its major food sources and assisted reproduction parameters. J Reprod Infertil 15: 214221.

35. Mendiola J, Torres-Cantero AM, Moreno-Grau JM, Ten J, Roca M, et al. (2009) Food intake and its relationship with semen quality: A case-control study. Fertil Steril 91: 812-818.

36. Chiu YH, Afeiche MC, Gaskins AJ, Williams PL, Mendiola J, et al. (2014) Sugar-sweetened beverage intake in relation to semen quality and reproductive hormone levels in young men. Hum Reprod 29: 1575-1584.

37. Chavarro JE, Toth TL, Sadio SM, Hauser R (2008) Soy food and isoflavone intake in relation to semen quality parameters among men from an infertility clinic. Hum Reprod 23: 2584-2590.

38. Souter I, Chiu YH, Batsis M, Afeiche MC, Williams PL, et al. (2017) The association of protein intake (amount and type) with ovarian antral follicle counts among infertile women: results from the EARTH prospective study cohort. BJOG 124: 15471555.

39. Karmon AE, Toth TL, Chiu YH, Gaskins AJ, Tanrikut C, et al. (2017) Male caffeine and alcohol intake in relation to semen parameters and in vitro fertilization outcomes among fertility patients. Andrology 5: 354-361.

40. Gaskins AJ, RichEdwards JW, Williams PL, Toth TL, Missmer SA, et al. (2018) Prepregnancy caffeine and caffeinated beverage intake and risk of spontaneous abortion. Eur J Nutr 57: 107-117.

41. Gaskins AJ, Rich-Edwards JW, Missmer SA, Rosner B, Chavarro JE (2015) Association of fecundity with changes in adult female weight. Obstet Gynecol 126: 850-858.

42. Orzylowska EM, Jacobson JD, Bareh GM, Ko EY, Corselli JU, $\mathrm{e}^{\mathrm{t} \text { al. }}$ (2016) Food intake diet and sperm characteristics in a blue zone: a Loma Linda Study. Eur J Obstet Gynecol Reprod Biol 203: 112115.

43. Gao M, Li B, Yuan W, Zhao L, Zhang X (2014) Hypothetical link between infertility and genetically modified food. Recent Pat Food Nutr Agric 6: 16-22.

44. Mumford SL, Chavarro JE, Zhang C, Perkins NJ, Sjaarda LA, et al. (2016) Dietary fat intake and reproductive hormone concentrations and ovulation in regularly menstruating women. Am J Clin Nutr 103: 868-877.

45. Karayiannis D, Kontogianni MD, Mendorou C, Douka L, Mastrominas M, et al. (2016) Association between adherence to the Mediterranean diet and semen quality parameters in male partners of couples attempting fertility. Hum Reprod 32: 215222.

46. Cutillas-Tolín A, Mínguez-Alarcón L, Mendiola J, López-Espín JJ, Jørgensen N, et al. (2015) Mediterranean and western dietary patterns are related to markers of testicular function among healthy men. Hum Reprod 30: 2945-2955.

47. Zareba P, Colaci DS, Afeiche M, Gaskins AJ, Jorgensen N, et al. (2013) Semen quality in relation to antioxidant intake in a healthy male population. Fertil Steril 100: 1572-1579.

48. Safarinejad MR, Dadkhah F, Asgari MA (2010) Relationship of omega- 3 and omega- 6 fatty acids with semen characteristics, and anti-oxidant status of seminal plasma: a comparison between fertile and infertile men. Clin Nutr 29: 100-105.

49. Gaskins AJ, Colaci DS, Mendiola J, Swan SH, Chavarro JE (2012) Dietary patterns and semen quality in young men. Hum Reprod 27: 2899-2907. 